\title{
Analisis terhadap Peranan Polri Sebagai Penyidik Dalam Tindak Pidana Penebangan Hutan Tanpa Izin (Penelitian Berkas Perkara Nomor BP/83/XI/2010/RESKRIM pada Polres Tulang Bawang)
}

\author{
Satrio Nur Hadi ${ }^{*}$, Tahura Malagano ${ }^{2}$ \\ ${ }^{1}$ Fakultas Hukum Universitas Mitra Indonesia \\ Negeri Sakti, Kabupaten Pesawaran, Lampung \\ ${ }^{2}$ Fakultas Hukum Universitas Mitra Indonesia \\ Pinang Jaya, Kemiling Bandar Lampung \\ *Correspondence email: satrionurhadi@umitra.ac.id; tahuramalagano@umitra.ac.id
}

\begin{abstract}
Abstrak. Pembangunan hutan adalah sasaran pembangunan nasional yang diharapkan dapat memberikan manfaat yang sebesarbesamya bagi kesejahteraan rakyat, temyata hal itu sekarang sangat sulit terjadi, karena banyaknya kasus-kasus penebangan hutan tanpa izin dari pejabat yang memiliki wewenang. Hal ini seperti kasus yang terjadi di Kawasan Hutan Register 45 Sungai Buaya Kabupaten Mesuji Lampung. Pada berkas perkara Nomor BP/83/XI/2010 RESKRIM pada Pokes Tulang Bawang bahwa tersangka yang bernama Komang Salie alias Komang Bon alias Wayan Putra bin Wayan Mije, diduga melakukan tindak pidana penebangan hutan tanpa izin pejabat yang berwenang, dalam perkara yang diduga setiap orang dilarang menduduki dan atau mengerjakan dan atau menggunakan, merambah, penebangan pohon dan memanen atau memungut hasil hutan tanpa memiliki hak serta izin dari pejabat yang memiliki wewenang serta membawa alat-alat yang khusus digunakan untuk menebang, memotong atau membelah pohon di dalam kawasan hutan tanpa izin pejabat berwenang, dan mereka yang melakukan, yang menyuruh melakukan, serta yang ikut serta dalam melakukan perbuatan atau mereka yang sengaja memberikan bantuan pada waktu kejahatan dilaksanakan atau mereka yang dengan sengaja memberikan kesempatan peluang, sarana untuk melakukan kejahatan itu, sebagaimana dimaksud dalam Pasal 50 ayat (3) huruf a,b,e, dan k Jo pasal 78 ayat (2), (5), dan (10) Undang-Undang Nomor 19 Tahun 2004 tentang Perubahan Atas Undang-Undang Nomor 41 Tahun 1999 tentang Kehutanan, Jo Pasal 55, 56 KUHP. Permasalahan dalam penelitian ini adalah bagaimanakah peranan Polri sebagai penyidik dalam tindak pidana penebangan hutan tanpa izin pejabat yang berwenang serta faktor apakah yang menjadi penghambat peranan Polri sebagai penyidik dalam tindak pidana penebangan hutan tanpa izin pejabat yang berwenang. Metode yang penulis pergunakan dalam penelitian ini adalah menggunakan pendekatan normatif dan empiris, jenis data primer dan sekunder, metode pengumpulan data dengan studi pustaka dan studi lapangan, dan analisis data secara diskriptif kualitatif. Berdasarkan hasil penelitan bahwa peranan Polri sebagai penyidik dalam tindak pidana penebangan hutan tanpa izin pejabat yang berwenang perkara nomor BP/83/XI/2010/RESKRIM pada Polres Tulang Bawang antara lain sebelum dilakukannya penyidikan maka terlebih dulu dilakukan penyelidikan guna menentukan kebenaran terhadap tindak pidana yang terjadi. Penyidikan didasarkan pada KUHAP dan Undang-Undang Nomor 02 Tahun 2002 tentang Kepolisian.
\end{abstract}

Kata Kunci: Penyidik; Tindak Pidana; Penebangan Hutan

\begin{abstract}
Forest development is a national development target that is expected to provide maximum benefits for the people's welfare, in fact this is now very difficult to happen, because there are many cases of logging without permission from the authorized official. This is the case in the Sungai Buaya Register 45 Forest Area, Mesuji Regency, Lampung. In the case file Number BP / 83 / XI / 2010 RESKRIM to the Tulang Bawang Pokes that the suspect named Komang Salie alias Komang Bon alias Wayan Putra bin Wayan Mije, is suspected of having committed a criminal act of logging without the permission of the authorized official, in a case which is suspected by everyone. prohibited from occupying and or working and or using, encroaching, cutting trees and harvesting or collecting forest products without having the right and permission from the authorized official and carrying tools specifically used to cut, cut or cut trees in the forest area without a permit authorized officials, and those who commit, who order to do, participate in the act or those who deliberately provide assistance at the time the crime is committed or those who deliberately provide opportunities, means to commit the crime, as referred to in Article 50 paragraph (3) letters a, $b$, e, and $k$ Jo Article 78 paragraph (2), (5), and (10) Law Number 19 of 2004 concerning Amendments to Law Number 41 of 1999 concerning Forestry, Jo Articles 55, 56 of the Criminal Code. The problem in this research is what is the role of the National Police as an investigator in the criminal act of logging without the permission of the authorized official and what factors are the factors that hinder the role of the Police as an investigator in the criminal act of logging without the permission of the authorized official. The method that the author uses in this research is to use normative and empirical approaches, primary and secondary data types, data collection methods with literature study and field studies, and descriptive qualitative data analysis. Based on the results of the research, the role of the National Police as an investigator in the crime of forest logging without the permission of the authorized official case number BP / 83 / XI / 2010 / RESKRIM at the Tulang Bawang Police, among others, before the investigation was carried out, an investigation was first carried out to determine the truth of the criminal act that occur. The investigation is based on KUHAP and Law Number 02 of 2002 concerning the Police.
\end{abstract}

Keywords: Investigator; Crime; Logging Forest 
Satrio Nur Hadi dan Tahura Malagano, Analisis terhadap Peranan Polri Sebagai Penyidik Dalam Tindak Pidana Penebangan Hutan Tanpa Izin (Penelitian Berkas Perkara Nomor BP/83/XI/2010/RESKRIM pada Polres Tulang Bawang)

\section{PENDAHULUAN}

Hutan merupakan salah satu sumber daya yang sangat penting yang berfungsi untuk pengaturan tata air, pencegahan banjir serta erosi, pemeliharaan kesuburan tanah serta pelestarian lingkungan hidup. Hutan sebagai sumber kekayaan alam yang dimiliki bangsa Indonesia merupakan salah satu modal dasar dalam pembangunan nasional yang dapat dipergunakan dalam rangka meningkatkan kesejahteraan dan kemakmuran rakyat yang dijelaskan dalam Pasal 33 ayat (3) Undang-Undang Dasar 1945 bahwa bumi air, serta kekayaan alam yang ada didalamnya dipergunakan sebesar-besarnya untuk kemakmuran rakyat. Pembangunan dan pelestarian hutan merupakan salah satu sasaran pembangunan nasional yang dapat diharapkan untuk memberikan manfaat sebesar-besarnya bagi kemakmuran serta kesejahteraan rakyat. ${ }^{1}$

Hutan merupakan salah satu modal pembangunan nasional memiliki manfaat dan peran nyata bagi kehidupan serta penghidupan bangsa Indonesia, dalam bentuk manfaat ekologi, sosial budaya serta ekonomi, secara seimbang dan dinamis. Dalam hal ini hutan harus diurus, dikelola, dilindungi serta dimanfaatkan secara berkesinambungan bagi kesejahteraan masyarakat Indonesia, baik generasi sekarang maupun masa yang akan datang.

Hutan sebagai kekayaan alam milik bangsa dan negara, maka hak-hak bangsa serta negara atas hutan dan hasilnya perlu dijaga dan juga dipertahankan supaya hutan dapat memenuhi fungsinya bagi kepentingan bangsa serta negara itu sendiri. Hutan sebagai sumber kekayaan alam milik bangsa Indonesia merupakan salah satu modal dasar pembangunan nasional yang digunakan dalam rangka meningkatkan kemakmuran dan kesejahteraan rakyat sebagaimana yang telah dijabarkan dalam Undang-Undang Dasar 1945. bahwa bumi air, serta kekayaan alam yang ada didalamnya dipergunakan untuk sebesar-besar kemakmuran rakyat.

Penguasaan kehutanan oleh negara bukanlah merupakan bentuk kepemilikan, namun negara memberikan wewenang kepada pemerintah dalam rangka mengatur serta mengurus segala sesuatu yang berkaitan dengan hutan, kawasan hutan serta hasil hutan; menetapkan kawasan hutan serta mengubah status kawasan hutan; mengatur dan menetapkan hubungan hukum antara orang dengan hutan atau kawasan hutan serta hasil hutan, serta mengatur perbuatan hukum mengenai kehutanan. Selanjutnya pemerintah memiliki wewenang dalam rangka memberikan izin serta hak kepada pihak lain dalam melakukan kegiatan di bidang kehutanan. ${ }^{2}$

Dalam pemanfaatan hutan dilaksanakan dengan cara pemberian izin pemanfaatan kawasan, izin pemanfaatan jasa lingkungan, izin pemanfaatan hasil hutan kayu serta izin pemanfaatan hasil hutan bukan kayu, izin pemungutan hasil hutan kayu dan bukan kayu. Selain mempunyai hak dalam memanfaatkan hasil hutan, pemegang izin juga harus bertanggung jawab atas segala macam gangguan terhadap hutan dan kawasan hutan serta dipercayakan kepadanya.

Pembangunan dan pelestarian hutan adalah salah satu sasaran pembangunan nasional yang juga dapat memberikan manfaat yang sebesar-besarnya bagi kemakmuran dan kesejahteraan rakyat, ternyata hal itu sekarang hanyalah sesuatu yang akan sulit terjadi, dikarenakan semakin maraknya tindak kejahatan penebangan hutan secara liar, serta penebangan hutan tanpa izin pejabat yang berwenang. Hal ini pernah terjadi dalam kasus di Kawasan Hutan Register 45 Sungai Buaya Kabupaten Mesuji Lampung.

Pada berkas perkara Nomor BP/83/XI/2010/RESKRIM pada Polres Tulang Bawang bahwa tersangka yang bernama Komang Salie alias Komang Bon alias Wayan Putra bin Wayan Mije, diduga melakukan tindak pidana penebangan hutan tanpa izin pejabat yang berwenang, dalam perkara yang diduga setiap orang dilarang menduduki atau mengerjakan dan atau menggunakan, merambah, menebang pohon ataupun memanen serta memungut hasil hutan tanpa memiliki hak atau izin dari pejabat yang berwenang serta membawa alat-alat yang lazim digunakan untuk menebang, memotong ataupun membelah pohon dalam kawasan hutan lindung tanpa seizin pejabat yang berwenang, serta mereka yang melakukan, yang menyuruh melakukan, dan yang turut serta melakukan perbuatan ataupun mereka yang dengan sengaja memberikan bantuan pada waktu kejahatan dilakukan, atau mereka yang dengan sengaja memberikan kesempatan, sarana untuk melakukan kejahatan itu, sebagaimana dimaksud dalam Pasal 50 Ayat (3) huruf a,b,e, dan k Jo Pasal 78 Ayat (2), (5), dan (10) Undang-Undang Nomor 19 Tahun 2004, perubahan atas UndangUndang Nomor 41 Tahun 1999 Tentang Kehutanan, Jo Pasal 55, 56 KUHP.

Guna penyidikan tindak pidana lebih lanjut, maka Kapolres Tulang Bawang melalui Kasat Reskrim mengeluarkan Surat Perintah Penyidikan Nomor SP.Sidik/237/XI/2010/Reskrim Tanggal 03 Nopember 2010, dengan perintah tugas melakukan penyidikan tindak pidana yang dimaksudkan, membuat resume penyidikan, dan melaporkan setiap perkembangan pelaksanaan penyidikan tindak pidana pada kesempatan pertama pada penyidik. Selanjutnya Kapolres Tulang Bawang melalui Kasat Reskrim menyampaikan Surat Pemberitahuan dimulainya Penyidikan Kepada Kejaksaan Negeri Tulang Bawang Nomor B/86/XI/2010/ Reskrim tanggal 11 Nopember 2010.

\footnotetext{
${ }^{1}$ Leden, Marpaung. Tindak Pidana Terhadap Hutan, Hasil Hutan dan Satwa. (Jakarta : Cet. 1. Erlangga). hlm. 15

2 Nurdjana, IGM., Teguh Prasetya dan Sukardi. 2005. Korupsi dan Illegal Logging. (Yogyakarta : Pustaka Pelajar). hlm. 9
} 
Satrio Nur Hadi dan Tahura Malagano, Analisis terhadap Peranan Polri Sebagai Penyidik Dalam Tindak Pidana Penebangan Hutan Tanpa Izin (Penelitian Berkas Perkara Nomor BP/83/XI/2010/RESKRIM pada Polres Tulang Bawang)

\section{METODE}

Pendekatan masalah dalam suatu penelitian dilakukan dengan cara pendekatan yuridis normatif dan empiris.

1. Pendekatan secara normatif

Pendekatan secara normatif adalah pendekatan dengan cara melakukan penelaahan dan pengkajian terhadap teoriteori, konsep-konsep, pandangan-pandangan yang diambil dari bahan kepustakaan berupa buku-buku, literaturliteratur, perundang-undangan, dokumen-dokumen yang berhubungan dengan peranan Polri sebagai penyidik dalam tindak pidana penebangan hutan tanpa izin.

2. Pendekatan secara empiris

Pendekatan secara empiris adalah pendekatan dengan cara melakukan penelitian langsung di lapangan untuk memperoleh gambaran nyata mengenai peranan Polri sebagai penyidik dalam tindak pidana penebangan hutan tanpa izin.

\section{HASIL DAN PEMBAHASAN}

\section{Peranan Polri Sebagai Penyidik Dalam Proses Penyidikan Tindak Pidana Penebangan Hutan Tanpa Izin Pejabat Yang Berwenang}

Berdasarkan hasil wawancara dengan Y. Agustiandaru selaku Penyidik di Kepolisian Resor Tulang Bawang mengatakan bahwa tindak pidana penebangan hutan tanpa izin pejabat yang berwenang dapat digambarkan sebagai berikut:

a. Identitas Tersangka

Tersangka bemama Komang Salie alias Komang Bon alias Wayan Putra Bin Wayan Mije, Umur 55 Tahun, Jenis Kelamin laki-Laki, pekerjaan tani Alamat Desa Trimulya Kampung Tirta Yoga Kecamatan Seputih Mataram Kabupaten Lampung Tengah.

b. Kronologis Kejadian

Pada hari Selasa tanggal 2 Nopember 2010 sekira jam 07.00 WIB diareal perkebunan PT. Silva Inhutani Lampung kawasan hutan register 45 tersangka Komang Salie alias Komang Bon alias Wayan Putra bin Wayan Mije telah menyuruh saksi Tumino bin Sakijo memotong, membelah kayu albasia yang telah ditebang untuk digunakan tersangka sebagai bahan mendirikan gubuk diareal tersebut, kemudian setelah kayu tersebut selesai dipotong dan dibelah menjadi berbentuk potongan-potongan kayu bulat dan papan selanjutnya tersangka mendirikan gubuk diareal tersebut yang dijadikan sebagai tempat tinggal tersangka Komang Bon alias Wayan Putra bin Wayan Mije bersama dengan saksi Tumino bin Sakijo.

Pada hari Rabu tanggal 03 Nopemberr 2010 sekira jam 10.00 WIB diareal perkebunan PT. Silva Inhutani Lampung kawasan hutan register 45 Blok VI, VII Divisi V-A dan blok IX Divisi VII-A2 Kabupaten Mesuji, tersangka Komang Salie alias Komang Bon alias Wayan Putra bin Wayan Mije telah menyuruh saksi Tumino bin Sakijo, Langkir bin Bejo, Warjo bin Warso, Suno bin Cokro Amonito, Wanto bin Pawiro Semito dan Naro bin Bejo Utomo menebang pohon albasia yang masih berdiri, dengan menggunakan senjata tajam jenis golok dan mesin senso, dengan tujuan akan menjadikan lahan tersebut menjadi lahan peladangan.

Pada hari Sabtu tanggal 2 Oktober 2010, sekira jam 10.00 WIB di areal perkebunan PT. Silva Inhutani Lampung kawasan hutan register 45 tersangka Komang Salie alias Komang Bon alias Wayan Putra bin Wayan Mije telah menerima penyerahan uang senilai Rp. 20.000.000,- (dua puluh juta rupiah) dari Ketut Suwarti sebagai pembayaran penjualan tanah kawasan hutan register 45.

Pada hari Rabu tanggal 13 Oktober 2010 sekira jam 12.00 WIB di areal perkebunan PT Silva Inhutani Lampung kawasan hutan register 45 tersangka Komang Salie alias Komang Bon alias Wayan Putra bin Wayan Mije telah menerima penyerahan uang senilai 5.000.000,- (lima juta rupiah) dari saksi Langkir bin Bejo, Warjo bin Warso, Suno bin Cokro Aminoto, Wanto bin Pawiro Semito sebagai pembayaran penjualan tanah kawasan hutan register 45 .

Dalam rangka penyidikan tindak pidana lebih lanjut, maka kapolres tulang bawang melalui Kasat Reskrip mengeluarkan Surat Perintah Penyidikan Nomor SP.Sidik/237/XI/2010/Reskrim tanggal 03 Nopember 2010, dengan perintah tugas melakukan penyidikan tindak pidana yang dimaksudkan, membuat resume penyidikan, dan melaporkan setiap perkembangan pelaksanaan penyidikan tindak pidana pada kesempatan pertama pada penyidik. Selanjutnya Kapolres Tulang Bawang melalui Kasat Reskrim menyampaikan Surat Pemberitahuan dimulainya Penyidikan Kepada Kejaksaan Negeri Menggala Nomor B/86/XI/2010/Reskrim tanggal 11 Nopember 2010.

Ditambahkan oleh Y. Agustiandaru bahwa petugas penyidik dalam memulai proses penyidikan suatu tindak pidana menggunakan parameter alat bukti yang sah serta sesuai dengan Pasal 184 KUHAP yang dikaitkan dengan segi tiga pembuktian (evidence triangle) guna memenuhi aspek legalitas serta aspek legitimasi dalam rangka membuktikan tindak pidana yang terjadi. Adapun rangkaian kegiatan penyidik dalam melaksanakan suatu penyidikan antara lain 
Penyelidikan, Penindakan, pemeriksaan dan penyelesaian berkas perkara. Setelah memperoleh informasi bahwa adanya suatu tindak pidana maka Pejabat Kepolisian dapat segera melakukan penyelidikan.

Setelah penyelidik telah menyelesaikan proses penyelidikan, maka penyelidik dapat segera membuat dan menyampaikan laporan hasil penyelidikan kepada penyidik. Apabila telah diketahuinya bahwa telah terjadi suatu peristiwa tindak pidana berdasarkan laporan dari penyelidik, dengan ini maka penyidik dapat segera melaksanakan penyidikan dalam rangka mencari serta mengumpulkan barang bukti, yang dengan barang bukti itu membuat terang tentang suatu tindak pidana yang terjadi serta guna menemukan tersangkanya.

Langkah awal yang dapat ditempuh penyidik Polres Tulang Bawang dalam penanganan perkara pidana khususnya perkara pidana penebangan hutan tanpa izin pejabat berwenang adalah dengan melakukan penyelidikan, penindakan, pemeriksaan, penyelesaian dan penyerahan berkas perkara. Berkaitan dengan hal tersebut penyidik telah dapat melakukan tugas penyidikan maka penyidik wajib memberitahukan kepada penuntut umum dengan surat pemberitahuan dimulainya penyidikan yang dilampiri dengan berita acara.

Berdasarkan hasil wawancara dengan Ferdi Selfiawan selaku Penyidik Pembantu Kepolisian Resor Tulang Bawang mengatakan bahwa pelaksanaan pemeriksaan terhadap tindak pidana penebangan hutan tanpa izin pejabat berwenang Perkara Nomor BP/83/XI/2010/RESKRIM, segera melakukan tindakan-tindakan berupa penindakan terhadap tindak pidana, pemeriksaan terhadap tindak pidana dan penyerahan berkas perkara.

1. Penindakan Terhadap Tindak Pidana.

Penindakan merupakan setiap tindakan hukum yang dilakukan terhadap seseorang ataupun benda yang tentunya ada hubungan dengan suatu tindak pidana yang terjadi.

Tindakan hukum dapat berupa pemanggilan tersangka serta saksi, penangkapan, penahanan, penggeledahan, dan juga penyitaan. ${ }^{3}$

a. Pemanggilan Tersangka dan Saksi.

Setelah penyidik telah memperoleh keterangan-keterangan yang jelas tentang tindak pidana yang terjadi dan siapa tersangkanya, maka dalam hal ini penyidik dapat segera melakukan pemanggilan kepada tersangka dan saksi untuk dapat didengar keterangannya. Penyidik mendengarkan keterangan tersangka dan saksi dengan pertimbangan bahwa seorang mempunyai peranan sebagai tersangka atau saksi dalam suatu tindak pidana yang telah terjadi, serta untuk melengkapi keterangan-keterangan, petunjuk-petunjuk serta bukti- bukti yang sudah didapat, tetapi dalam beberapa hal masih terdapat beberapa kekurangan.

b. Penangkapan

Penangkapan merupakan pengekangan sementara waktu terhadap kebebasan tersangka apabila telah cukup bukti guna kepentingan penyidikan. Pemeriksaan tersebut dimaksudkan untuk dapat menentukan perlu tidaknya diadakan proses penahanan, mengingat jangka waktu Penangkapan yang diberikan oleh Kitab Undang-Undang Hukum Acara Pidana yaitu hanya 1 x 24 jam.

c. Penahanan.

Maksud dari penahanan ini antara lain agar supaya tersangka tidak melarikan diri (alasan subjek), tidak akan merusak dan menghilangkan barang bukti, dan atau akan mengulangi tindak pidana lagi.

d. Penggeledahan.

Penggeledahan dilaksanakan berdasarkan hasil laporan penyelidikan yang dibuat oleh petugas penyidik/penyidik pembantu. Untuk penggeledahan rumah dapat dilaksanakan dalam rangka kepentingan penyidikan saja. Guna menjamin hak azasi manusia atau seorang atas rumah kediamannya, dalam melakukan penggeledahan harus memiliki surat izin dari Ketua Pengadilan Negeri dan surat perintah penggeledahan.

e. Penyitaan.

Penyitaan merupakan sekumpulan tindakan penyidik dalam rangka mengambil alih menyita, ataupun menyimpan untuk kepentingan pembuktian dalam penyidikan, penuntutan dan juga peradilan. Dalam hal ini tertangkap tangan oleh petugas polisi maka barang bukti langsung dapat disita, misalnya alat yang digunakan untuk melakukan suatu tindak pidana. Dalam hal penggeledahan rumah penyitaan harus dilakukan dengan izin Ketua Pengadilan Negeri. Menurut KUHAP yang dapat dikenakan penyitaan antara lain :

1) Benda dan tagihan tersangka yang seluruhnya ataupun sebagian diduga diperoleh dari hasil suatu tindak pidana;

2) Benda yang telah dipergunakan secara langsung dalam melakukan suatu tindak pidana atau untuk mempersiapkannya;

3) Benda yang dipergunakan dalam menghalang-halangi penyidikan tindak pidana;

4) Benda yamg khusus dibuat ataupun diperuntukkan melakukan suatu tindak pidana;

5) Benda lain yang mempunyai hubungan langsung dengan tindak pidana yang dilakukan;

${ }^{3}$ Soekanto, Soerjono. 2001. Penanggulangan Kejahatan. (Jakarta : Rajawali Pers) hlm. 16 
6) Benda yang berada dalam sitaan perkara perdata atau pailit sepanjang memenuhi ketentuan sebagaimana tersebut pada huruf a, b, c, d, e.

2. Pemeriksaan terhadap tindak pidana

Guna melakukan proses pemeriksaan terhadap suatu tindak pidana, dilakukan tahap-tahap antara lain :

a. Pemeriksaan Tersangka.

Sesuai dengan asas praduga tak bersalah, maka seseorang yang diduga melakukan tindak pidana pemeriksaan yang dilakukan penyidik dalam melakukan pemeriksaan terhadap seseorang yang melakukan tindak pidana.

b. Pemeriksaan Saksi.

Setelah tersangka diperiksa, selanjutnya saksi yang ganti diperiksa. Saksi adalah seseorang yang memberikan keterangan guna kepentingan penyidikan, penuntutan, serta peradilan tentang suatu peristiwa pidana yang ia dengar sendiri, ia lihat sendiri, dan ia alami sendiri sehingga saksi merupakan alat bukti yang sah. Tujuan dilaksanakannya suatu pemeriksaan saksi yaitu untuk lebih menguatkan/keyakinkan penyidikan terhadap tersangka apabila ia benar-benar melakukan tindak pidana atau bahkan sebaliknya. Oleh sebab itu saksi tidak boleh hanya satu orang dan paling sedikit dua orang. Untuk melakukan pemeriksaan terhadap tersangka yang melakukan tindak pidana seorang petugas polisi/penyidik, disamping harus menguasai pendidikan tentang kepolisian juga harus menguasai ilmu psychiatrie, sosiologi sosiale, paedagogie, serta antropologi dan juga apabila dipandang perlu dalam melakukan pemeriksaan terhadap tersangka tindak pidana.

3. Penyerahan Berkas Perkara.

Proses penyidikan dilakukan dalam rangka untuk mencari serta mengumpulkan bukti yang dengan bukti tersebut dapat membuat terang tindak pidana yang terjadi dan telah ditemukan tersangkanya, Penyidik membuat berita acara tentang pelaksanaan tindakan. Berita acara dibuat untuk setiap tindakan tentang pemeriksaan tersangka; penangkapan; penahanan; penggeledahan; pemasukan rumah; penyitaan benda; pemeriksaan surat; pemeriksaan saksi; pemeriksaan di tempat kejadian; pelaksanaan penetapan dan putusan pengadilan; pelaksanaan tindakan lain sesuai dengan ketentuan dalam undang-undang ini. Setelah berkas perkara sudah dianggap lengkap, maka Penyidik menyerahkan berkas perkara kepada penuntut umum. Penyerahan berkas perkara dilakukan dengan cara pada tahap pertama penyidik hanya menyerahkan berkas perkara, dalam hal penyidikan sudah dianggap selesai, penyidik menyerahkan tanggung jawab atas tersangka dan barang bukti kepada penuntut umum. ${ }^{4}$

Berdasarkan kasus Berkas Perkara Nomor BP/83/XI/2010/RESKRIM pada Polres Tulang Bawang perkara pidana penebangan hutan tanpa izin pejabat berwenang telah dilaksanakan penyidikan oleh para penyidik Polres Tulang Bawang. Dalam rangka penyidikan perkara pidana tersebut Kapolres Tulang Bawang melalui Kasat Reskrim mengeluarkan Surat Perintah Penyidikan Nomor SP.Sidik/237/XI/2010/Reskrim Tanggal 03 Nopember 2010, memerintahkan kepada:

a. Ipda Iwan Dharmawan, SH

b. Aiptu A. Cik Wijaya

c. Brigpol Muhajirin

d. Brigpol Ika Dwi Hayatman

e. Brigpol Siswoyo

f. Brigpol Kasno DY

g. Brigpol Sugiarto

h. Brigpol Iwantori

i. Briptu Iwantori

j. Briptu si Priyanto

Melakukan penyidikan tindak pidana penebangan hutan tanpa izin pejabat yang berwenang, dalam perkara yang diduga setiap orang dilarang menduduki dan atau mengerjakan dan atau menggunakan, merambah, menebang pohon atau memanen atau memungut hasil hutan tanpa memiliki hak atau izin dari pejabat yang berwenang dan membawa alat-alat yang lazim digunakan untuk menebang, memotong atau membelah pohon di dalam kawasan hutan tanpa izin pejabat yang berwenang, dan mereka yang melakukan, yang menyuruh melakukan, dan yang turut serta melakukan perbuatan atau mereka yang sengaja memberi bantuan pada waktu kejahatan dilakukan, atau mereka yang sengaja memberi kesempatan, sarana untuk melakukan kejahatan itu, sebagaimana dimaksud dalam pasal 50 Ayat (3) huruf a,b,e, dan k Jo Pasal 78 Ayat (2), (5), dan (10) Undang-Undang Nomor 19 Tahun 2004, perubahan atas UndangUndang Nomor 41 Tahun 1999 tentang Kehutanan Jo Pasal 55, 56 KUHP, membuat penyidikan, dan melaporkan setiap perkembangan pelaksanaan penyidikan tindak pidana pada kesempatan pertama pada penyidik.

${ }^{4}$ Hamzah, Andi. 2003. Asas-Asas Hukum Pidana. (Jakarta: Rineka Cipta). hlm. 19 
Satrio Nur Hadi dan Tahura Malagano, Analisis terhadap Peranan Polri Sebagai Penyidik Dalam Tindak Pidana Penebangan Hutan Tanpa Izin (Penelitian Berkas Perkara Nomor BP/83/XI/2010/RESKRIM pada Polres Tulang Bawang)

Berdasarkan resume penyidikan Berkas Perkara Nomor BP/83/XI/2010/ Reskrim diperoleh fakta-fakta sebagai berikut:

1. Penangkapan

Dengan surat perintah penangkapan Nomor Sp.Kap/192/XI/2010/Reskrim, tanggal 3 Nopember 2010 telah dilakukan penangkapan terhadap tersangka Komang Salie alias Komang Bon alias Wayan Putra bin Wayan Mije.

2. Penahanan

Dengan surat perintah penahanan Nomor Sp.Han/138/XI/2010/Reskrim tanggal 4 Nopember 2010 telah dilakukan penahanan terhadap tersangka Komang Salie alias Komang Bon alias Wayan Putra bin Wayan Mije.

3. Penyitaan

a. Dengan surat perintah penyitaan Nomor Sp.Sita/198/XI/2010/Reskrim tanggal 03 Nopember 2010 telah dilakukan penyitaan terhadap barang bukti dari tersangka Komang Salie alias Komang Bon alias Wayan Putra bin Wayan Mije, berupa :

1) 1 (satu) unit kendaraan roda dua merek Honda Tipe NF11B1DM/T, tahun pembuatan 2009, warna hitam Nomor Polisi BE 3352 GP, Nomor Mesin JBC2E1195347, Nomor rangka MH1JBC2199K191936, Nomor BPKB 0659675F.

2) 1 (satu) lembar Surat Tanda Nomor Kendaraan bermotor Nomor Polisi BE 3352 GP an. Komang Sayle.

3) 1 (satu) lembar surat ketetapan pajak daerah Nomor Polisi BE 3352 GP an. Komang Sayle.

4) 1 (satu) buah kunci kontak motor merek honda.

5) 1 (satu) lembar kertas kwitansi tanggal 13 Oktober 2010

6) 3 (tiga) lembar kertas bukti setoran melalui Bank Mandiri masing- masing tanggal 24 Agustus 2010 jumlah uang Rp. 3.000.000,- (tiga juta rupiah) penerima an. Herwansyah, tanggal 21 September 2010 jumlah uang Rp. 7.000.000,- (tujuh juta rupiah), penerimaan. Herwansyah dan tanggal 23 Sepetmber 2010 jumlah uang Rp. 5.000.000,- (lima juta rupiah) penerima an. Herwansyah.

b. Dengan surat perintah penyitaan Nomor Sp.Sita/199/XI/2010/Reskrim tanggal 03 Nopember 2010 telah dilakukan penyitaan terhadap barang bukti dari saksi Tumino bin Sakijo brupa 1 (satu) unit gergaji mesin senso merek Motoyama 375 P, 063 G warna orange.

c. Dengan surat perintah penyitaan Nomor Sp.Sita/200/XI/2010/Reskrim tanggal 10 Nopember 2010 telah dilakukan penyitaan terhadap barang bukti dari saksi Dayat bin Amrin berupa :

1) 2 (dua) keping kayu albasia berbentuk papan;

2) 2 (dua) keping pecahan asbes;

3) 2 (dua) batang kayu albasia berbentuk bulat.

4. Keterangan Saksi

Telah dilakukan pemanggilan saksi-saksi untuk dimintai keterangan, antara lain:

a. Rusmana, S.Hut bin Jainudin

b. Baharudin bin Rustam

c. Samio bin Tukiman

d. Jantje alias Daniel bin Ganyantjun

e. Tumino bin Sakijo

f. Warjo bin Warso

g. Suni bin Cokro Aminoto

h. Wanto bin Pawiro Sumito

5. Keterangan ahli

Nama Germy Togatorop, pekerjaan Pegawai Negeri Sipil Bagian Pengukur Batas kawasan hutan badan UPTD inventarisasi dan pemetaan hutan Dinas Kehutanan Propinsi Lampung.

6. Bukti surat

a. Surat Keputusan Menteri Kehutanan Republik Indonesia Nomor 785/Kpts- 11/1993 tanggal 22 Nopember 1993 tentang Kelompok Hutan Register 45 Sungai Buaya.

b. Berita Acara Rekonstruksi batas kawasan hutan register 45 yang dilakukan oleh kantor wilayah Departemen Kehutanan dan Perkebunan tahun 1996.

c. Peta rekonstruksi kawasan hutan produksi tetap sungai buaya register 45 Kabupaten Tulang Bawang Februari 2006.

d. Berkas berita acara pengukuhan tata batas kawasan hutan produksi tetap 45 register 45 sungai buaya Lampung Utara 1986/1987.

e. Surat Keputusan Menteri Kehutanan Republik Indonesia Nomor 93/Kpts-11/1997 tanggal 17 Februari 1997 tentang Pemberian Hak Penguasaan Tanaman Industri Areal Hutan seluas 43.100 hektar.

7. Barang bukti

a. Disita dari tersangka Komang Salie alias Komang Bon alias Wayan Putra bin Wayan Mije, berupa : 
1) 1 (satu) unit kendaraan roda dua merek Honda Tipe NF11B1DM/T, tahun pembuatan 2009, wama hitam Nomor Polisi BE 3352 GP, Nomor JBC2E1195347, Nomor rangka MH1JBC2199K191936, Nomor BPKB 0659675F.

2) 1 (satu) lembar Surat Tanda Nomor Kendaraan bermotor Nomor Polisi BE 3352 GP an. Komang Sayle.

3) 1 (satu) lembar surat ketetapan pajak daerah Nomor Polisi BE 3352 GP an. Komang Sayle.

4) 1 (satu) buah kunci kontak motor merek honda.

5) 1 (satu) lembar kertas kwitansi tanggal 13 Oktober 2010

6) 3 (tiga) lembar kertas bukti setoran melalui Bank Mandiri masing- masing tanggal 24 Agustus 2010 jumlah uang Rp. 3.000.000,- (tiga juta rupiah) penerima an. Herwansyah, tanggal 21 September 2010 jumlah uang Rp. 7.000.000,- (tujuh juta rupiah), penerima an. Herwansyah dan tanggal 23 Sepetmber 2010 jumlah uang Rp. 5.000.000,- (lima juta rupiah) penerima an. Herwansyah.

b. Disita darl saksi Tumino bin Sakijo berupa 1 (satu) unit gergaji mesin senso merek Motoyama 375 P, $063 \mathrm{G}$ warna orange pad tanggal 3 Nopember 2010.

c. Disita dari saksi Dayat bin Amrin pada tanggal 10 Nopember 2010 berupa:

1) 2 (dua) keping kayu albasia berbentuk papan;

2) 2 (dua) keping pecahan asbes;

3) 2 (dua) batang kayu albasia berbentuk bulat.

8. Kesimpulan

Setelah penyidik mempelajari keterangan para saksi dan tersangka yang dikuatkan dengan barang bukti penyidik berpendapat bahwa perbuatan tersangka Komang Salie alias Komang Bon alias Wayan Putra bin Wayan Mije sudah memenuhi unsur delik yang tercantum dalam pasal 50 ayat 3 huruf a,b,e dan k Jo Pasal 78 ayat 2, 5, dan 10 Undang-Undang Nomor 19 Tahun 2004, perubahan atas Undang Undang Nomor 41 Tahun 1999 tentang Kehutanan Jo Pasal 55, 56 KUHP. Untuk itu perkara tersebut dapat ditingkatkan ke tahap penuntutan.

\section{Faktor Yang Menjadi Penghambat Peranan Polri Sebagai Penyidik Dalam Tindak Pidana Penebangan Hutan Tanpa Izin Pejabat Yang Berwenang}

Pada dasarnya pihak kepolisian tidak banyak kesulitan baik di dalam melakukan Penangkapan maupun dalam melakukan peyidikan. Polres Tulang Bawang tidak begitu banyak mengalami kesulitan karena pihak Polres selalu mempertimbangkan baik buruknya terhadap segala persoalan yang menyangkut tindakan yang dilakukan oleh tersangka, dalam melakukan penyidikan Polres Tulang Bawang selalu menerapkan sistem kekeluargaan sehingga dengan sendirinya mereka merasa diperhatikan, tidak merasa takut dan pada akhirnya terbuka sendiri nuraninya memberikan jawaban yang terus terang pada setiap pertanyaan yang diajukan oleh penyidik.

Namun demikian hambatan-hambatan yang sering dijumpai dalam menangani tindak pidana pada Polres Tulang Bawang antara lain sebagai berikut:

1. Lokasi TKP jauh dari pemukiman penduduk.

2. Keterbatasan sarana, prasarana dan personil untuk penangani kasus pidana

3. Keterbatasan biaya dalam penyidikan perkara pidana.

\section{Ad. 1. Lokasi TKP jauh dari pemukiman penduduk.}

Mendatangi Tempat Kejadian Perkara (TKP) yang jaraknya jauh dari pemukiman penduduk dan tidak dapat ditempuh dengan keadaan baik roda empat atau roda sdua, sehingga mendatangai TKP dengan berjalan kaki serta jarak yang cukup jauh, lokasi TKP jauh dari pemukiman penduduk sering menjadi kendala dalam menangani tindak pidana.

\section{Ad. 2. Keterbatasan sarana, prasarana dan personil}

Untuk menangani kasus pidana, sarana yang digunakan masih terbatas begitu juga dengan jumlah anggota yang menangani bermacam-macam kejadian dengan tuntunan waktu semuanya harus terpenuhi. Kepolisian Resort Tulang Bawang keterbatasan personil untuk menangani kasus tindak pidana, karena banyaknya kasus tindak pidana yang terjadi di Kabupaten Tulang Bawang membuat keterbatasan personil dalam Kepolisian Resor Tulang Bawang. Banyak kasus tindak pidana yang harus segera diselesaikan dalam jangka waktu secepatnya.

\section{Ad.3. Keterbatasan biaya dalam penyidikan perkara pidana}

Guna melakukan proses penyidikan terhadap suatu tindak pidana membutuhkan biaya yang tidak sedikit untuk memperlancar proses penyidikan. Biaya yang dikeluarkan untuk melakukan proses penyidikan biasanya menggunakan uang dari pihak penyidik itu sendiri, karena apabila menunggu anggaran dari atasan justru akan memperlambat proses penyidikan. Namun dalam hal ini uang yang dimiliki oleh seorang penyidik tidaklah cukup untuk menutup anggaran 
yang dikeluarkan selama melakukan proses penyidikan. Sehinga anggaran untuk proses penyidikan dalam tindak pidana haruslah segera dianggarkan dan segera dikeluarkan untuk dapat digunakan sebagaimana mestinya.

\section{SIMPULAN}

Berdasarkan hasil penelitian dan pembahasan pada bab sebelumnya, maka dapat disimpulkan sebagai berikut:

1. Peranan penyidik dalam penyidikan tindak pidana penebangan hutan tanpa izin perkara nomor BP/83/XI/2010/RESKRIM pada Polres Tulang Bawang antara lain sebelum dilakukannya penyidikan maka terlebih dulu dilakukan penyelidikan guna menentukan kebenaran terhadap tindak pidana yang terjadi. Penyidikan didasarkan pada KUHAP dan dalam Undang-Undang Nomor 2 Tahun 2002 tentang Kepolisian. Selanjutnya langkah-langkah dalam melakukan penyidikan tindak pidana penebangan hutan tanpa izin adalah penindakan terhadap tindak pidana, pemeriksaan terhadap tindak pidana, penyerahan berkas perkara kepada Penuntut Umum.

2. Faktor yang menjadi penghambat peranan Polri sebagai penyidik dalam tindak pidana penebangan hutan tanpa izin pejabat yang berwenang adalah sebagai berikut:

a. Lokasi TKP jauh dari pemukiman penduduk.

b. Keterbatasan sarana, prasarana dan personil untuk penangani kasus pidana

c. Keterbatasan biaya dalam penyidikan perkara pidana.

\section{DAFTAR PUSTAKA}

Bassar, Sudradjat. 2006. Tindak-tindak Pidana Tertentu Dalam Kitab Undang-Undang Hukum Pidana. CV. Remadja Karya. Bandung.

Chazawi, Adami. 2005. Pelajaran Hukum Pidana Bagian 1. Raja Grafindo Persada. Jakarta.

Hamzah, Andi. 2003. Asas-Asas Hukum Pidana. Rineka Cipta. Jakarta.

Lamintang, P.A.F. 2003. Dasar-dasar Hukum Pidana Indonesia. Penerbit: PT. Citra Aditya Bakti. Bandung.

Leden, Marpaung. Tindak Pidana Terhadap Hutan, Hasil Hutan dan Satwa. Cet. 1. Erlangga. Jakarta.

Moeljatno. 2005. Asas-Asas Hukum Pidana. PT. Rineka Cipta. Jakarta.

Muhammad, Abdulkadir. 2004. Hukum dan Penelitian Hukum. PT Citra Aditya Bakti. Bandung.

Nurdjana, IGM., Teguh Prasetya dan Sukardi. 2005. Korupsi dan Illegal Logging. Pustaka Pelajar. Yogyakarta.

Prodjodikoro, Wirjono. 2000. Asas-Asas Hukum Pidana di Indonesia. Refika Aditama. Bandung.

Soedarto. 1990. Hukum dan Hukum Pidana. Penerbit Alumni. Bandung.

Soekanto, Soerjono. 2001. Penanggulangan Kejahatan. Rajawali Pers. Jakarta.

Widiyanti, Nanik. 2002. Perkembangan Kejahatan dan Masalahnya Ditinjau dari Segi Kriminologi dan Sosial. PT. Pradnya Paramita. Jakarta. 